\title{
The Effectiveness of Aloe vera Hydrogel Against Fusobacterium nucleatum
}

\author{
Chandra Susanto, Ermi Girsang* \\ Biomedics Study Programme, Faculty of Medicine, Universitas Prima Indonesia, Medan-Indonesia \\ Submitted 11 March 2020; Revised 14 April 2020; Accepted 24 August 2020; Published 30 October 2020 \\ *Corresponding author: Ermigirsang@gmail.com
}

\begin{abstract}
Bacteria can cause infectious diseases on oral health such as gingivitis and periodontitis. Scaling and rootplaning are effective against this disease, nevertheless several types of antimicrobial material can be added to increase the effectiveness of the initial treatment. Aloe vera is one of the natural antimicroba materials that is usually used. Hydrogel is a polymetric material that is stable in wet conditions, especially in the gingival sulcus. Sodium alginate is a natural polymer that is often used to produce hydrogels due to its biocompability. The aim of this study was to know the the effectiveness of Aloe vera hydrogel against Fusobacterium nucleatum by in vitro method. This research is experimental research with a total of 20 samples. The samples used were $5 \%$ and $10 \%$ sodium alginate based Aloe vera hydrogel which were placed in pure culture of F. nucleatum in MHA media for 24 hours. The inhibition zone diameter were measured using calipers. The results of the study using Shapiro-Wilk normality test showed that the data were not normally distributed. Then Kruskal Wallis test was performed which showed significant differences in each treatment group followed by Post Hoc Mann Whitney test to see a significant difference in the $5 \%$ group and $10 \%$. Aloe vera hydrogel showed a significant inhibition against $F$. nucleatum bacteria at both $5 \%$ and $10 \%$ concentrations.
\end{abstract}

Keywords: Alginate, Aloe vera, Antimicrobial material, Fusobacterium nucleatum, Hydrogel, Inhibitory zone

\section{Efektivitas Hidrogel Aloe vera terhadap Bakteri Fusobacterium nucleatum}

\begin{abstract}
Abstrak
Bakteri memiliki beberapa faktor virulensi yang dapat menyebabkan penyakit infeksi seperti gingivitis dan periodontitis. Perawatan periodontal manual seperti skeling dan penyerutan akar dapat dilakukan pada penyakit inflamasi gingiva, untuk menambah efektifitas perawatan dapat ditambahkan dengan beberapa jenis antimikroba. Salah satu bahan herbal alami yang sering digunakan sebagai alternatif bahan antimikroba adalah Aloe vera. Hidrogel merupakan bahan polimetrik yang stabil dalam keadaan basah khususnya di dalam sulkus gingiva. Sodium alginat merupakan polimer natural yang sering digunakan untuk menghasilkan hidrogel dikarenakan sifat biokompabilitas. Penelitian ini bertujuan untuk mengevaluasi daya hambat hidrogel Aloe vera terhadap bakteri Fusobacterium nucleatum. Jenis penelitian ini adalah penelitian eksperimental dengan jumlah sampel sebanyak 20 yaitu bahan hidrogel Aloe vera berbasis sodium alginat 5\% dan 10\% yang ditempatkan pada biakan murni $F$. nucleatum di media MHA selama 24 jam. Diameter daya hambat diukur menggunakan kaliper. Dilakukan uji normalitas Shapiro-Wilk pada seluruh data hasil penelitian dan hasil penelitian menunjukkan data tidak terdistribusi normal. Dilakukan uji Kruskal-Wallis yang menunjukkan adanya perbedaan signifikan pada setiap kelompok dan dilanjutkan dengan uji Post Hoc Mann whitney untuk melihat perbedaan signifikan pada kelompok 5\% dan 10\%. Hidrogel Aloe vera memiliki daya hambat yang signifikan terhadap bakteri F. nucleatum baik pada konsentrasi 5\% dan $10 \%$.

Kata Kunci: Alginate, Aloe vera, Bahan antimikroba, Daya hambat, Fusobacterium nucleatum, Hidrogel
\end{abstract}




\section{Pendahuluan}

Penyakit inflamasi gingiva merupakan salah satu penyakit yang paling sering terjadi di rongga mulut. ${ }^{1}$ Salah satu bakteri patogen utama yang dapat menyebabkan penyakit gingiva adalah Fusobacterium nucleatum ( $F$. nucleatum). ${ }^{2}$

Perawatan dengan bahan antimikroba biasa telah menjadi perawatan yang sangat sering dilakukan sehingga hal ini dapat menyebabkan resistensi bakteri terhadap bahan antimikroba ${ }^{3}$. Oleh karena itu, dibutuhkan penelitian lebih lanjut mengenai bahan herbal alami. ${ }^{4}$ Salah satu bahan herbal alami yang paling sering digunakan sebagai alternatif dalam menggantikan bahan antimikroba adalah Aloe vera. ${ }^{5}$

Aloe vera merupakan bahan herbal yang dapat berubah konsistensi menjadi hidrogel tanpa penambahan bahan lainnya. ${ }^{6}$ Hal ini merupakan salah satu keuntungan dalam menggunakan Aloe vera sehingga bahan ini dapat digunakan sebagai alternatif bahan antimikroba yang nantinya akan dipakai secara langsung pada poket periodontal dan berfungsi dalam perawatan penyakit inflamasi gingiva yaitu periodontitis. ${ }^{7}$

Penggunaan bahan antimikroba secara lokal memiliki arti yaitu obat secara langsung ditempatkan di dalam sisi yang terkena penyakit sehingga konsentrasi yang dicapai 100 kali lebih tinggi dibandingkan dengan pemberian secara sistemik. ${ }^{8}$ Persiapan bentuk bahan antimikroba yang akan ditempatkan secara lokal pada jaringan periodontal dapat berupa gel, fiber, strip dan chip. ${ }^{9}$

Hidrogel merupakan bahan polimetrik yang memiliki kemampuan untuk mempertahankan komponen air dengan jumlah yang signifikan dan mampu bertahan selama mungkin dalam sukus gingiva dikarenakan hidrogel bersifat hidrofilik. ${ }^{10}$

Sodium alginat merupakan polimer natural yang sudah banyak digunakan untuk perawatan beberapa tipe luka oleh karena sifat biokompabilitas, biodegradibilitas dan kemampuan untuk membentuk hidrogel. ${ }^{11}$

Uji efektifitas ekstrak aloevera konsentrasi 2,5,5,10 dan 15\%,terhadapbakteri Agregatibacter actinomycetemcomitans menunjukkan daya hambat kuat pada konsentrasi 5 dan 10\%, sangat kuat pada konsentrasi 20\% sedangkan konsentrasi 2.5\% menunjukan hasil resisten. ${ }^{12}$

Penelitian mengenai aplikasi hidrogel Aloe vera berbasis sodium alginat dalam bidang biomedikal konsentrasi 5, 15 dan 25\% menunjukkan hasil positif yang dipengaruhi Aloe vera pada lapisan transparan hidrogel baik pada kondisi kering maupun basah, Aloe vera juga meningkatkan sifat hidropilik hidrogel sehingga dapat bertahan dalam keadaan basah selama 10 minggu. ${ }^{13}$

Berdasarkan latar belakang tersebut maka perlu dilakukan penelitian mengenai uji daya hambat hidrogel Aloe vera terhadap bakteri patogen periodontal lainnya yaitu $F$. nucleatum secara in vitro. Hal ini bertujuan untuk membuktikan efektifitas hidrogel Aloe vera sehingga nantinya hidrogel Aloe vera dapat digunakan sebagai salah satu alternatif bahan antimikroba dalam merawat penyakit inflamasi gingiva khususnya periodontitis.

\section{Metode}

2.1. Jenis dan Tempat Penelitan

Penelitian yang dilakukan merupakan penelitian eksperimental laboratorium yang dilakukan di laboratorium Biologi Oral Fakultas Kedokteran Universitas Airlangga Surabaya.

\subsection{Alat}

Neraca analitik (Boeco), laminar airflow cabinet (Astec HLF 1200L), autoklaf (Express Equipment), inkubator (Memmeth), kamera digital, peralatan gelas yang biasanya digunakan di laboratorium (Pyrex), bola karet, botol, batang pengaduk, kaliper, kertas Whatmann no.1, tabung reaksi dan rak petri dish, lampu spiritus, ose, kabin cabinet serta alat laboratorium tambahan.

\subsection{Bahan}

Aloe vera barbadensis Miller, sodium alginat (PT Graha Jaya Pratama), Mueller Hinton Agar (Oxoid, Germany), aquabidestillata steril (PT Ikapharmindo Putramas Pharmaceutical Laboratories) dan biakan murni bakteri Fusobacterium 
nucleatum yang diperoleh dari Biologi Oral Fakultas Kedokteran Universitas Airlangga Surabaya.

\subsection{Prosedur Penelitian}

2.4.1. Pembuatan Hidrogel Aloevera 5\% dan $10 \%$

Ekstrak lidah buaya diperoleh dengan teknik menghaluskan daun lidah buaya dengan ukuran panjang sekitar $50 \mathrm{~cm}$ dan ketebalan 2,5 cm yang dibersihkan dari duri dan kotoran. Lidah buaya yang telah dibersihkan ditambah etanol $70 \%$ dan dilakukan pengadukan selama hampir 30 menit dengan penggunaan magnetic stirrer dan distabilkan selama hampir 48 jam. Kemudian hasil tersebut disaring beberapa kali menggunakan buchner funnel dan dilapisi kertas saring kemudian dimasukan ke dalam erlenmeyer. Hasil saring ini diuapkan menggunakan vakum evaporator putaran. Kemudian bahan ini diencerkan menggunakan akuades. Persiapan lapisan hidrogel dilakukan dengan metode solvent casting. Larutan sodium alginat $(1,5 \% \mathrm{w} / \mathrm{v})$ dan Aloe vera $(1,0 \% \mathrm{w} / \mathrm{v})$ yang telah disiapkan ditambahkan gliserol 15\% (w/w) berdasarkan masa alginat yang bertujuan untuk menambah sifat fleksibilitas dari bahan. Bahan tersebut dicampurkan untuk menghasilkan konsentrasi $5 \%$ dan $10 \%(\mathrm{v} / \mathrm{v}), 25 \mathrm{ml}$ setiap campuran diletakkan pada cawan petri dan dibiarkan kering pada temperatur $25^{\circ} \mathrm{C}$ dan kelembaban terkontrol (50\%). Setelah dikeringkan campuran tersebut dimasukkan ke dalam larutan kalsium klorida $\left(\mathrm{CaCl}_{2}\right) 5,0 \%(\mathrm{w} / \mathrm{v})$ selama 5 menit sehingga diperoleh lapisan bahan dalam bentuk hidrogel seperti pada Gambar 1.

2.4.2. Uji Efektifitas Bahan Terhadap Bakteri a. Pembuatan Media Bakteri

Alat-alat dan media disterilkan sebelum dipakai menggunakan autoklaf pada suhu $121{ }^{\circ} \mathrm{C}$ selama 25 menit. Media bakteri dibuat menggunakan 12 gram bubuk Mueller Hinton Agar yang dilarutkan ke dalam 120 $\mathrm{ml}$ aquadest untuk 20 petri $(20 \mathrm{ml} /$ petri $)$, kemudian diletakkan pada magnetic heater sampai mendidih. Media tersebut disterilkan menggunakan autoklaf selama 20 menit dan tekanan uap 2 atm dengan suhu $121^{\circ} \mathrm{C}$. Media kemudian diletakan dalam freezer. Media tersebut akan dipanaskan kembali hingga mendidih jika akan digunakan kembali kemudian dituang ke cawan petri dan ditunggu hingga dingin.

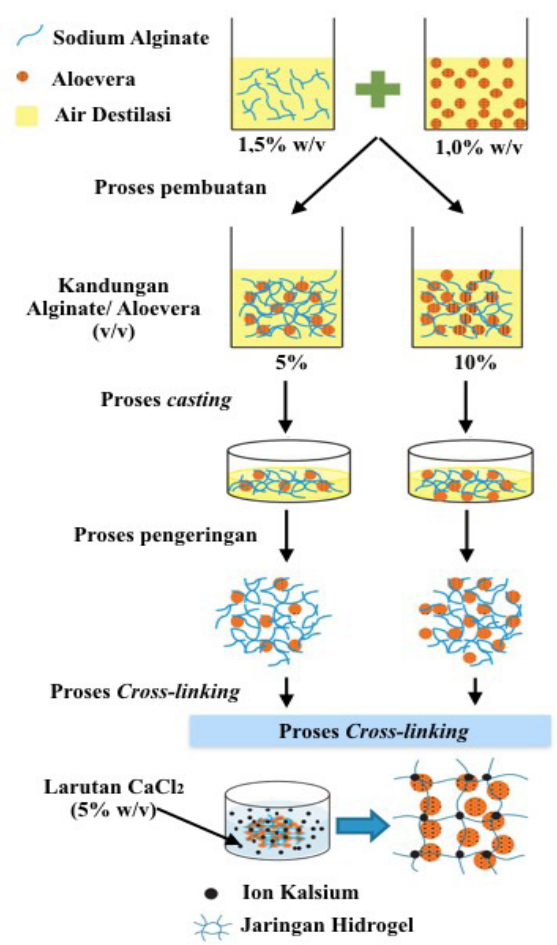

Gambar 1. Proses Pembuatan Hidrogel Aloe vera 
b. Pembiakan Spesimen

Suasana anaerob dibutuhkan sewaktu ingin membiakkan bakteri tersebut menggunakan inkubator $\mathrm{CO}_{2}$. Biakan $F$. nucleatum yang akan digunakan merupakan sel punca bakteri tersebut yang dikultur murni pada media Muller Hinton Agar (MHA). 1-2 ose kultur murni bakteri tersebut dibiakkan dan disuspensikan menggunakan larutan $\mathrm{NaCl}$ 0,9\% sampai mencapai kekeruhan yang telah disesuaikan dengan standar 0,6 Mc Farland yaitu sebesar jumlah bakteri 1 x $106 \mathrm{CFU} /$ ml. Media Muller Hinton Agar (MHA) yang telah steril dikeluarkan dari dalam freezer dan dibiarkan terlebih dulu dalam suhu ruangan. Bunsen dihidupkan untuk memanaskan ose agar ose menjadi steril. Setelah itu bakteri $F$. nucleatum diambil spesimennya dari media Muller Hinton Agar (MHA) dan pada saat media tersebut dibuka harus didekatkan dengan bunsen sehingga kontaminasi bakteri F. nucleatum dapat dihindari.

\section{c. Metode difusi agar}

Pada media MHA yang telah diinokulasikan bakteri, dibuat lubang menggunakan suatu cincin metal steril yang diameternya disesuaikan. Bahan coba yang dipakai yang terdiri dari konsentrasi 5\%, $10 \%$ dan kontrol dimasukkan menggunakan mikropipet ke dalam setiap kertas cakram yang telah diletakkan di media MHA. Setiap tindakan tersebut diulangi sebanyak 4 kali dan kemudian diletakkan dalam inkubator dengan derajat suhu $37^{\circ} \mathrm{C}$ selama 48 jam. Clear zone yang terbentuk pada sekitar lubang diukur menggunakan kaliper atau jangka sorong.

\section{Hasil}

Penelitian ini bertujuan untuk mengevaluasi efek daya hambat hidrogel Aloe vera terhadap bakteri Fusobacterium nucleatum. Konsentrasi hidrogel Aloe vera yang diuji adalah 5\% dan 10\%. Akuades dalam MHA berperan sebagai kelompok kontrol. Masing-masing bahan tersebut diteteskan ke dalam media Mueller Hinton Agar (MHA) yang telah dikultur bakteri $F$. nucleatum dan diinkubasi selama 1 hari, perlakuan tersebut dilakukan sebanyak 5 kali. Efektifitas gel tetrasiklin dievaluasi melalui diameter daya hambat media Mueller Hinton Agar (MHA) dan diukur menggunakan Kaliper. Data hasil zona hambat pertumbuhan Fusobacterium nucleatum pada kelompok (kontrol), hidrogel Aloe vera $5 \%$ dan hidrogel Aloe vera $10 \%$ terlihat di Tabel 4.1.

Dari tabel tersebut, didapatkan bahwa ukuran diameter daya hambat terbesar terlihat pada kelompok I sebesar 0,5 $\mathrm{mm}$ dan ukuran diameter terkecil adalah sebesar $0,2 \mathrm{~mm}$. Ukuran diameter zona hambat terbesar pada kelompok II adalah sebesar 12,0 mm dan ukuran diameter terkecil sebesar 11,4 mm. Ukuran diameter zona hambat terbesar pada kelompok III sebesar 13,2 mm dan ukuran diameter terkecil sebesar 12,6 mm. Dari hasil penemuan tersebut juga ditemukan adanya perbedaan dari ukuran diameter zona hambat terbesar dan terkecil antar kelompok. Hal ini

Tabel 4.1. Distribusi Data Zona Hambat Hidrogel Aloe vera konsentrasi 5\%, 10\% dan Kontrol terhadap Bakteri F. nucleatum

\begin{tabular}{cccc}
\hline & \multicolumn{3}{c}{ Zona Hambat $(\mathrm{mm})$} \\
\cline { 2 - 4 } No & Hidrogel Aloe vera \\
& Kontrol & $5 \%$ & $10 \%$ \\
\hline 1 & 0,2 & 11,8 & 12,6 \\
2 & 0,5 & 12,0 & 13,0 \\
3 & 0,3 & 11,7 & 13,2 \\
4 & 0,2 & 11,6 & 13,2 \\
5 & 0,4 & 11,4 & 12,8 \\
\hline
\end{tabular}

Hasil dalam skala mm 
menunjukkan bahwa semakin meningkatnya konsentrasi hidrogel Aloe vera maka peningkatan ukuran diameter daya hambat juga semakin meningkat. Grafik distribusi normal zona hambat hidogel Aloe vera dapat dilihat pada Gambar 2.

Uji normalitas Shapiro-Wilk menunjukkan data zona hambat pertumbuhan $F$. nucleatum pada kelompok aquadest (kontrol), hidrogel Aloe vera 5\%, hidrogel Aloe vera $10 \%$, tidak terdistribusi normal, dengan nilai $\mathrm{p}<0,05$. Data uji normalitas Shapiro-Wilk terlihat pada Tabel 4.2.

Data yang telah diperoleh menggunakan uji normalitas Shapiro-Wilk menunjukkan distribusi data tidak normal $(\mathrm{P}<0,05)$, sehingga dilanjutkan dengan uji Kruskal Wallis. Nilai rerata daya hambat pertumbuhan $F$. nucleatum untuk kelompok (kelompok kontrol) adalah sebesar 3,00 \pm $0,148 \mathrm{~mm}$, rerata daya hambat pertumbuhan F. nucleatum pada kelompok hidrogel Aloe vera $5 \%$ sebesar $13,00 \pm 0,224 \mathrm{~mm}$ dan rerata daya hambat pertumbuhan $F$. nucleatum pada kelompok ditambah hidrogel Aloe vera $10 \%$ adalah sebesar 18,00 \pm 0,261 mm (Tabel 4.3). Uji Kruskal Wallis menunjukkan nilai p yang dihasilkan adalah $0,000 *(<0,05)$.

Perbandingan zona hambat masingmasing hidrogel Aloe vera 5\%, 10\% dan kontrol terhadap bakteri Fusobacterium nucleatum dilakukan dengan uji MannWhitney dikarenakan data tidak terdistribusi normal dan setelah didapatkan adanya perbedaan signifikan antara konsentrasi dengan uji Kruskal-Wallis.

Uji statistik Post Hoc Mann Whitney menunjukkan nilai $\mathrm{P}$ yang dihasilkan dari tiap kelompok adalah sebesar $0,000 *(<0,05)$ yang berarti adanya perbedaan signifikan di setiap kelompok perlakuan (Tabel 4.4).

\section{Pembahasan}

Rerata nilai zona hambat pertumbuhan bakteri Fusobacterium nucleatum untuk kelompok I adalah sebesar 3,00 $\pm 0,148$, rataratazona hambat pertumbuhan Fusobacterium nucleatum untuk kelompok II adalah sebesar $13,00 \pm 0,224$ dan rata-rata zona hambat pertumbuhan Fusobacterium nucleatum untuk kelompok III adalah sebesar 18,00 \pm 0,261 . Peningkatan ukuran diameter zona hambat pada hidrogel Aloe vera konsentrasi $5 \%$ dan 10\% tampak terjadi pada hasil penelitian yang dilakukan, semakin tinggi konsentrasi Aloe vera, zona hambat juga akan semakin besar. ${ }^{14}$

Hasil penelitian J Supreet et al (2016) mendukung hasil penelitian ini, penelitian ini menunjukkan adanya efek antibakteri Aloe vera terhadap bakteri Actinobaccilus actinomycetemcomitans, Clostridium bacili, Streptococcus mutans, dan Staphylococcus aureus. Aloe vera memiliki efek yang paling besar terhadap bakteri-bakteri tersebut pada konsentrasi $100 \%$ dengan rata-rata daya hambat sebesar $6,9 \mathrm{~mm}$ pada bakteri Actinobaccilus actinomycetemcomitans, 6,3 $\mathrm{mm}$ terhadap Clostridium bacili, $6,8 \mathrm{~mm}$ terhadap Streptococcus mutan dan 6,6 mm terhadap Staphylococcus aureus. ${ }^{5}$

Hasil diameter daya hambat yang terbentuk juga didukung dengan hasil penelitian yang dilakukan oleh Jain $\mathrm{S}$ et al

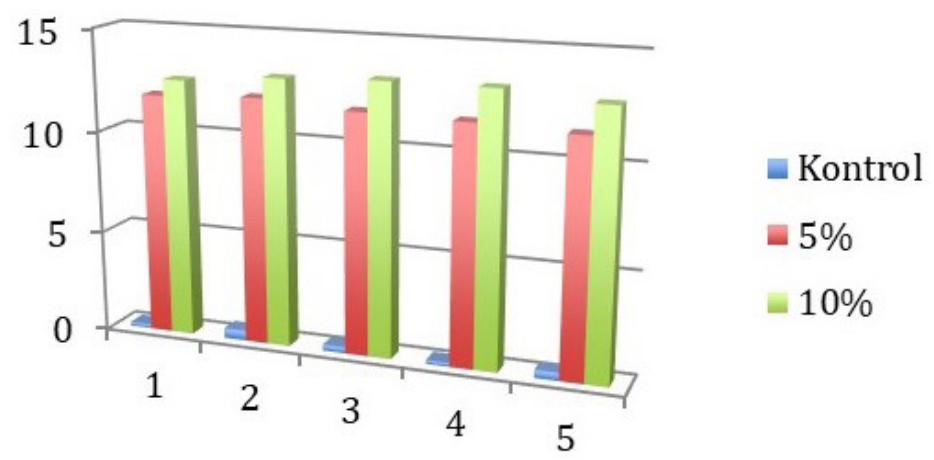

Gambar 2. Grafik Distribusi Normal Zona Hambat 
Tabel 4.2. Uji Normalitas Data Zona Hambat Hidrogel Aloevera konsentrasi 5\%, 10\% dan Kontrol terhadap Bakteri F. nucleatum

\begin{tabular}{cc}
\hline Kelompok & P \\
\hline Kontrol & 0,001 \\
Hidrogel Aloe vera $5 \%$ & 1,000 \\
Hidrogel Aloe vera $10 \%$ & 0,421 \\
\hline
\end{tabular}

Uji Shapiro-wilk

Data dikatakan terdistribusi normal jika $\mathrm{P}>0,05$

(2017). Penelitian tersebut menunjukkan daya hambat yang terbentuk pada gel Aloe vera konsentrasi $5 \%$ dan $10 \%$ terhadap Streptococcus mutans, Staphylococcus aureus dan Actinobaccilus actinomycetemcomitans. Rerata besaran diameter daya hambat terbesar terdapat pada konsentrasi $20 \%$ sekitar $7,1 \mathrm{~mm}$, 6,8 mm pada bakteri Streptococcus mutans dan $6,5 \mathrm{~mm}$ pada bakteri Actinobaccilus actinomycetemcomitans. ${ }^{15}$

Berdasarkan klasifikasi respon hambatan pertumbuhan bakteri (Greenwood, 1995), sensitivitas Fusobacterium nucleatum terhadap hidrogel Aloe vera konsentrasi 2,5\% pada penelitian ini tergolong lemah, sensitivitas Fusobacterium nucleatum hidrogel Aloe vera konsentrasi 5\% tergolong sedang, sensitivitas Fusobacterium nucleatum hidrogel Aloe vera konsentrasi 10\% tergolong kuat, dan sensitivitas Fusobacterium nucleatum hidrogel Aloe vera konsentrasi 10\% tergolong sangat kuat. Kemampuan bahan alami seperti Aloe vera dalam meningkatkan daya antibakteri tampak terjadi pada hasil penelitian ini. Hal ini ditandai oleh diameter daya hambat yang terbentuk tergolong sangat kuat pada konsentrasi $10 \% .^{16}$

Hasil uji daya hambat hidrogel
Aloe vera $5 \%$ dan $10 \%$ terhadap bakteri Fusobacterium nucleatum menunjukkan adanya zona bening pada media Muller Hinton Agar yang berbentuk lingkaran di sekitar kertas cakram. Zona bening tersebut mengindikasikan adanya efektifitas antibakteri dari masing-masing bahan obat. Hasil pengukuran diameter zona hambat bahan dengan rerata diatas $10 \mathrm{~mm}$ menunjukkan masing-masing konsentrasi bahan memiliki daya hambat yang kuat terhadap bakteri Fusobacterium nucleatum. ${ }^{17}$ Berdasarkan penelitian Davis dan Stout (2015), diameter daya hambat yang terbentuk pada uji difusi berukuran $<5 \mathrm{~mm}$ memiliki daya hambat yang lemah. Diameter daya hambat berukuran 5-10 $\mathrm{mm}$ termasuk sedang, $10-19 \mathrm{~mm}$ termasuk kuat dan $20 \mathrm{~mm}$ atau lebih termasuk sangat kuat. ${ }^{39}$ Berdasarkan pernyataan tersebut, hidrogel Aloe vera 5\% dan $10 \%$ memiliki efek antibakteri yang sangat kuat. ${ }^{18}$

Hasil penelitian ini menunjukkan bahwa hidrogel Aloe vera $10 \%$ memiliki efektifitas paling tinggi terhadap bakteri Fusobacterium nucleatum, tetapi efektifitas hidrogel Aloe vera $5 \%$ berbasis kitosan juga sangat tinggi. Hasil ini didukung penelitian Prasad S (2017), bahwa gel Aloe vera 50\%

Tabel 4.3. Nilai Mean Zona Hambat Hidrogel Aloe vera Konsentrasi 5\%, 10\% dan Kontrol terhadap Bakteri $F$. nucleatum

\begin{tabular}{cccc}
\hline Kelompok & $\mathrm{n}$ & Zona hambat & $\mathrm{P}$ \\
\cline { 3 - 4 } & & $(\mathrm{mm})(\mathrm{X} \pm \mathrm{SD})$ & \\
Kontrol & 5 & $3,00 \pm 0,148$ & $0,000^{*}$ \\
Hidrogel Aloe vera $5 \%$ & 5 & $13,00 \pm 0,224$ & \\
\hline
\end{tabular}

Uji Kruskal-wallis, *Signifikan $\mathrm{p}<0,05$ 
Table 4.4. Perbandingan Zona Hambat Hidrogel Aloe vera masing-masing konsentrasi 5\%, 10\% dan Kontrol terhadap Bakteri F. nucleatum

\begin{tabular}{ccc}
\hline Kelompok I & Kelompok II & Nilai P \\
\hline \multirow{2}{*}{ Kontrol } & $5 \%$ & $0,000^{*}$ \\
& $10 \%$ & $0,000^{*}$ \\
$5 \%$ & $10 \%$ & $0,000^{*}$ \\
\hline
\end{tabular}

Uji Post Hoc Mann Whitney, *Signifikan $p<0,005$

memiliki sifat biokompatibel terhadap sel fibroblas gingiva dan efektif terhadap bakteri patogen periodontal ${ }^{19}$. Hasil ini juga didukung oleh penelitian Yang $\mathrm{K}$ et al (2018) yang menunjukkan bahwa hidrogel dengan penambahan beberapa bahan antimikroba lebih efektif terhadap bakteri patogen periodontal yang bersifat anaerob dan pelepasan bahan antimikroba tersebut lebih terkontrol. ${ }^{20}$

Dalam 25 tahun terakhir, telah terdapat lebih dari 100 penelitian yang telah membandingkan bakteri penyakit yang dihubungkan plak dengan bakteri yang ditemukan pada plak yang dihubungkan dengan kesehatan periodontal. Penelitianpenelitian dari berbagai laboratorium yang melibatkan sejumlah besar sampel dan menggunakan metode yang beragam, menunjukkan bahwa bakteri anaerob seperti A. actinomycetemcomitans lebih mungkin untuk ada atau mendominasi dalam plak yang terkait dengan penyakit. Penelitian yang dilakukan Popa L (2013) menyatakan bahwa Fusobaterium nucleatum, $P$. gingivalis, dan $T$. denticola adalah bakteri anaerob lainnya yang paling sering ditemukan. Oleh karena itu, uji daya hambat hidrogel Aloe vera $5 \%$ dan $10 \%$ pada penelitian ini dilakukan terhadap bakteri Fusobacterium nucleatum. ${ }^{21}$

Berdasarkan analisis data menggunakan uji statistik Kruskal-Wallis, terlihat perbedaan signifikan $(p<0,05)$ dari rerata zona hambat pertumbuhan Fusobacterium nucleatum pada setiap kelompok. Uji Post Hoc Mann Whitney juga menunjukkan perbedaan signifikan $(p<0,05)$ dari nilai rata-rata zona hambat pertumbuhan Fusobacterium nucleatum kelompok 5\% terhadap kelompok $10 \%{ }^{22}$

\section{Simpulan}

Kedua konsentrasi hidrogel Aloe vera $5 \%$ dan $10 \%$ efektif dalam menghambat pertumbuhan bakteri $F$. nucleatum. Walaupun demikian pada penelitian ini terlihat hidrogel Aloe vera konsentrasi $10 \%$ lebih efektif dalam menghambat pertumbuhan bakteri $F$. nucleatum dibandingkan konsentrasi 5\%.

\section{Daftar Pustaka}

1. Carranza Fermin A, Takei Henry H. The Treatment Plan. In Carranza's clinical periodontology. 12th edition, St. Louis, saunders-Elsevier; 2012: 125-26.

2. Han W. Fusobacterium nucleatum: a commensal turned pathogen. J dent Res; 2015; 1:141-47.

3. Signat B, Roques C, Poulet P, Duffaut D. Role of Fusobacterium Nucleatum in Periodontal Health and Disease. Horizonpress; 2013; 13: 25-36.

4. Kotsilkov K, Popova C, Dosseva V. Effectiveness of Target Antimicrobial Therapy of Severe Chronic Periodontitis Part i: Reduction of Gingival Inflamation and Active Periodontal disease Sites. Jimab; 2010; 16(4): 18-20.

5. Jain $\mathrm{S}$ et al. Antibacterial effect of Aloe vera Gel against Oral Pathogens: an invitro study. Journal of Dentistry; 2016; 10(11): 41-44.

6. Fani M, Kohanteb J. Inhibitory activity of Aloe vera gel on some clinically isolated cariogenic and periodontophatic bacteria. Journal of oral Science; 2012; 54(1): 1521.

7. Sangur R, Bajwa W, Mahajan T, Banerjea A. Aloe Vera: An Acient Option for Modern Day Dental Problems A Review. 
Journal of Dentistry; 2016; 3(8): 235153.

8. A.L Dumitrescu. The topical use of antibiotics in periodontal pockets. In: Antibiotics and antiseptics in periodontal therapy. Verlag Berlin Heidenberg. Spring; 2011: 171.

9. Setiawati E. The Effectiveness of $0.5-0.7 \%$ Tetracycline Gel to Reduced Subgingival Plaque Bacteria. M kedokteran Gigi; 2010; 41(3): 114-17.

10. Rathod H, Mehta D. A Review on Pharmaceutical Gel. ASIJPS; 2015; 1(1): 33-47.

11. Aljohani W et al. Application of Sodium Alginate Hydrogels. IOSR-JBB; 2017; 3(3): 19-31.

12. Pereira R, Mendes A, Bartolo P. Alginate/ Aloe vera hydrogel films for biomedical applications. Elsevier; 2016; 10(15); 21015.

13. Rieuwpassa IE, Rahmat, Karlina. Daya hambat ekstrak Aloe vera terhadap pertumbuhan Staphylococcus aureus (studi in vitro). Dentofasial Jurnal kedokteran gigi; 2011; 10(2); 65-70.

14. Sahu $\mathrm{P}$ et al. Therapeutic and Medicinal Uses of Aloe vera: A Review. Pharmacology \& Pharmacy; 2014; 4(1); 1-12.

15. Wardani, A.K. Uji Aktivitas Antibakteri Fraksi Residu Ekstrak Etanolik Daun
Arbenan (Duchesnea indica (Andr. Facke.) terhadap Staphylococcus aureus dan Pseudomonas aeruginosa Multiresisten Antibiotik Beserta Profil Kromatografi Lapis Tipis. Jurnal Biologi Oral; 2011; 10(2);23-25.

16. Wilson, S.G., H.M. Dick. 2014. Topley and Wilson Principle of Bacteriology, Virology and Immunity. 14th ed, England:John Wiley \& Sons, Ltd; 2014; 273-74.

17. Chandra S, Irma E, Harry A. In vitro evaluation of antimicrobial effectiveness chitosan based tetracycline gel on some pathogen periodontal bacteria. IJADS; 2017; 3(2); 71-76.

18. Larsen $\mathrm{T}$ and Fiehn N. Dental Biofilm Infections an Update. APMIS; 2017; 125(2); 376-84.

19. Manakil J. Periodontal diseasesa clinician's Guide. 3rd ed, England:Intechopen; 2012; 145-46.

20. Yang $\mathrm{K}$ et al. Antimicrobial Hydrogels: Promising Materials for Medical Application. IJN; 2018; 1(3): 2217-63.

21. Popa L, Ghica M, Pirvu C. Periodontal Chitosan Gels Designed for Improved Local Intra Pocket drug Delivery. Farmacia; 2013; 61(2): 240-50.

22. Melvin W et al. Performance Standards for Antimicrobial Susceptibility Testing. 27th ed, USA: CLSI; 2017; 151-155. 